\title{
An Approach for the Assessment of E-Government Benefits to Governments, citizens and Businesses
}

\section{Saad Haj Bakry", Zeyad Haj Bakry and Fahad Bin Muhaya}

King Saud University, Riyadh, Saudi Arabia

*Corresponding author: Saad Haj Bakry, Professor, King Saud University, Riyadh, Saudi Arabia, Tel: +966114670000; E-mail: shb@ksu.edu.sa

Rec date: Feb 27 2016; Acc date: Mar 15, 2016; Pub date: Mar 19, 2016

Copyright: ( 2016 Barky SH, et al. This is an open-access article distributed under the terms of the Creative Commons Attribution License, which permits unrestricted use, distribution, and reproduction in any medium, provided the original author and source are credited.

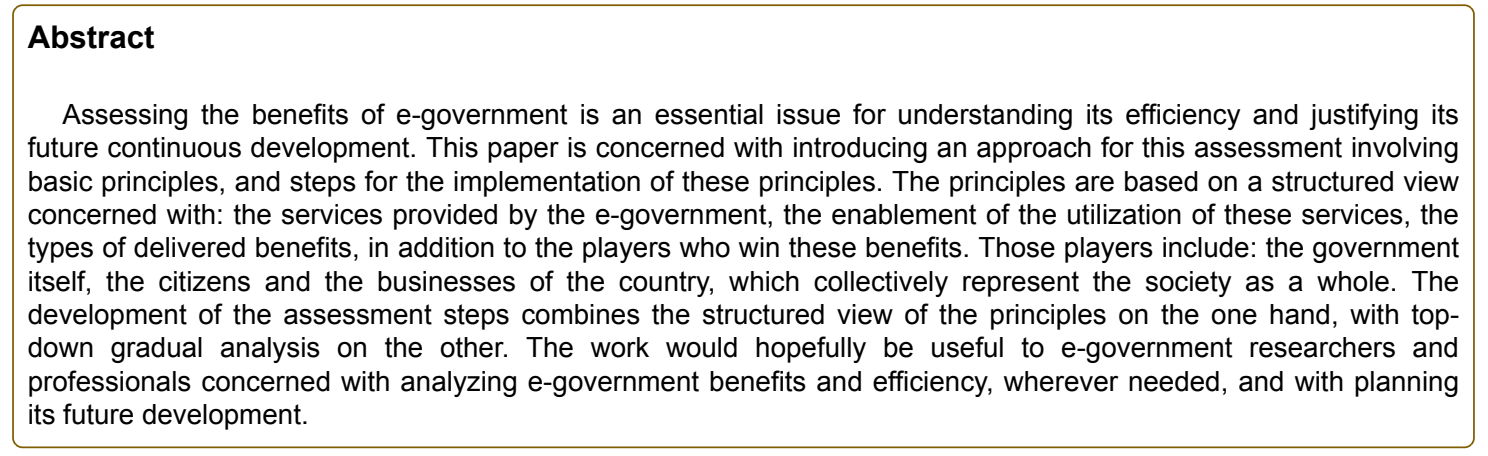

Keywords: E-Government benefits; E-Government utilization; EGovernment efficiency; E-Government impact

\section{Introduction}

This section addresses the subject of e-government assessment in general, with emphasizes on the assessment of its benefits in particular. It reviews the assessment method of the Department of Economic and Social Affairs (DESA) of the United Nations (UN), as this is the most widely known method that provides annual assessment results on the state of development of e-government in various countries, in addition to ranking them according to their states. It shows that while the method addresses different issues, including e-government use, it does not assess its benefits. The objectives of the paper are then presented and, its contents are introduced.

\section{Assessment of E-Government}

Planning and development of e-government is a continuous process that demands continuous assessment in order to respond to the fast development of the technology and the continuous change of requirements. Various e-readiness [1] and e-government assessment methods [2] have been developed for different purposes. The most important of these methods is the method used by the UNDESA for the annual assessment and ranking of the state of e-government in different countries [3].

\begin{tabular}{|c|c|c|c|c|}
\hline \multicolumn{2}{|l|}{ Dimension } & Issue & Factor & Source \\
\hline \multirow{11}{*}{$\begin{array}{l}\text { E-Government } \\
\text { Infrastructure }\end{array}$} & \multirow[t]{5}{*}{ Communication Index } & Computers & \multirow[t]{5}{*}{ Number per 100 persons } & \multirow[t]{5}{*}{ National statistics } \\
\hline & & Internet & & \\
\hline & & Fixed Telephone & & \\
\hline & & Mobile Telephone & & \\
\hline & & Fixed Broadband & & \\
\hline & \multirow[t]{6}{*}{ On-line Services Index } & \multirow{6}{*}{$\begin{array}{l}\text { Essential Government Services } \\
\text { Websites }\end{array}$} & National site & \multirow[t]{6}{*}{ Survey studies } \\
\hline & & & Education & \\
\hline & & & Labor & \\
\hline & & & Social services & \\
\hline & & & Health & \\
\hline & & & Finance & \\
\hline
\end{tabular}




\begin{tabular}{|c|c|c|c|c|}
\hline & & \multirow[t]{5}{*}{ Services Development Stages } & Subsidiary sites & \\
\hline & & & Emerging & \\
\hline & & & Enhanced & \\
\hline & & & Transactional & \\
\hline & & & Connected & \\
\hline \multirow[t]{5}{*}{ E-Government use } & \multirow[t]{2}{*}{ Human Capital Index } & & Adult literacy index & National statistics \\
\hline & & & Gross enrollment index & \multirow[t]{4}{*}{ Survey studies } \\
\hline & \multirow[t]{3}{*}{ E-Participation } & & Information & \\
\hline & & & Consultation & \\
\hline & & & Decision making & \\
\hline
\end{tabular}

Table 1: E-Government assessment method of UNDESA.

The UNDESA method has two main dimensions. The first is concerned with the technical infrastructure of e-government; while the second is associated with its use. The assessment of the technical infrastructure has two indices: the "communication index" and the "on-line services index". The assessment of e-government also has two indices: the "human capital index" and the "e-participation index". The "communication index" and the "human capital index" are based on conventional national statistics usually available on the websites of national departments and international organizations; while the "online services index" and the "e-participation index" require survey studies. A recent study of this type is given in [4]. Table 1 presents the method and shows the various factors associated with its main indices.

\section{Assessment of benefits}

The UNESA assessment method does not assess the benefits of the e-government; and in the available literature, no other method seems to have done so. However, a paper based on a PhD thesis has addressed the benefits of information networks considering the capacity of different networking technologies and their performance. That analysis was applied to a banking network of Automatic Teller Machines (ATM) [5]. Some points concerned with the classification of benefits were useful to the work presented here in this paper.

The work presented in this paper aims at developing an approach for the assessment of e-government benefits to governments, citizens, businesses, and consequently to whole societies. The approach involves: initiating principles upon which the assessment is based; and providing assessment steps that implement the principles. The work would be useful in assessing the current state of e-government benefits in any addressed country, and in the future planning of its development.

\section{Approach Principles}

The assessment of e-government benefits proposed here is based on four main principles. These principles can be briefly identified by the following four questions.

- What are the services that deliver the benefits?

- How the benefits of these services can be enabled?
- How the benefits can be viewed?

- Who are the winners of the resulting benefits?

The integration of the issues associated with these questions would form a general essential framework upon which the assessment of the benefits of e-government can be based. Figure 1 illustrates the general integration of these principles. In the following, each of the principles is identified with further details.

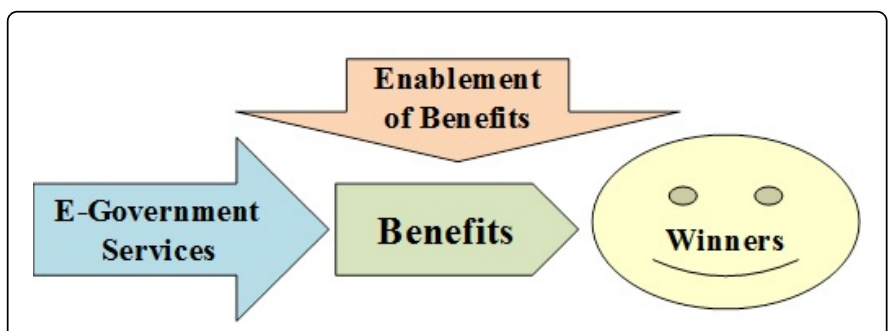

Figure 1: A basic framework for the assessment of e-government benefits.

\section{E-Government services}

The e-government services are well-addressed by the infrastructure indices of the UNDESA method, which include: the communication index and the online services index explained in Table 1. The online services index, which is concerned with the delivered services, is related not only to the fields of the services, but also to their level of intelligence. It considers four stages of intelligence: "emerging, enhanced, transactional and connected". With the continuous development of information technology, further stages of intelligence are expected in the future [6].

\section{Enablement of the benefits}

E-government benefits can only be enabled through the utilization of its services. The main source of utilization is the people both: as individuals, and as professionals associated with business organizations. The e-government benefits would increase with the increase of the volume of users. This "volume" depends of course on 
Citation: Bakry SH, Bakry ZH, Muhaya FB (2016) An Approach for the Assessment of E-Government Benefits to Governments, citizens and

Page 3 of 5

the size of the population and the size of the business companies. However, other factors need to be taken into account per egovernment service; and these include:

- The "source factor", which identifies the part of the population, and of the business, concerned with the e-government service considered.

- The "capability" of the source, with regards to using the egovernment service considered, among those associated with the source factor;
- The "interest" level toward using the service, among those who enjoy the capability and concerned with the service.

For enhancing e-government services and supporting the enablement of benefits, continuous public awareness need to be considered, especially with the upgrading of services and their intelligence, and with the introduction of new services. Table 2 summarizes the above, and highlights the need for continuous development.

\begin{tabular}{|c|c|c|c|}
\hline \multirow[t]{2}{*}{ Source } & \multicolumn{2}{|c|}{ Source of Utilization } & \multirow[t]{3}{*}{ Development } \\
\hline & $\begin{array}{l}\text { People: } \\
\text { Citizens }\end{array}$ & Business: Companies & \\
\hline Volume & Population & No. of Companies & \\
\hline Source Factor & \multicolumn{2}{|c|}{ Who is concerned with using the service? } & \multirow{3}{*}{$\begin{array}{l}\text { Continuous public awareness } \\
\text { and } \\
\text { interest support }\end{array}$} \\
\hline Capability & \multicolumn{2}{|c|}{ Who has the capability of using the service? } & \\
\hline Interest & \multicolumn{2}{|c|}{ Toward using the service } & \\
\hline
\end{tabular}

Table 2: Enablement factors associated with each e-government service.

\section{The benefits}

- The e-government benefits can be viewed according to three main dimensions; and these can be expressed by the following main questions:

- Are the benefits repeated with the repetition of transactions, or are they gained, but not on repetition basis; in other words, are they recursive or non-recursive?
- Are they delivered directly, or are they indirect or even hidden; in other words, are they tangible or intangible?

- Do they result in savings relative to non e-services, or do they open new opportunities?

By considering these three dimensions in combination, eight potential types of benefits result. These are given in Table 3 with an example of each type of benefit.

\begin{tabular}{|l|l|l|l|l|}
\hline \multirow{2}{*}{ Types of Benefits } & \multicolumn{2}{|l|}{ Recursive: Repeated } & Non-recursive: Not repeated \\
\cline { 2 - 5 } & $\begin{array}{l}\text { Tangible: } \\
\text { Direct }\end{array}$ & Intangible: Indirect & $\begin{array}{l}\text { Tangible: } \\
\text { Direct }\end{array}$ & Intangible: Indirect \\
\hline $\begin{array}{l}\text { Saving: } \\
\text { On basic commodities }\end{array}$ & Movement to perform transactions & Human tension & Work space & Complexity \\
\hline $\begin{array}{l}\text { Original: New } \\
\text { Opportunities }\end{array}$ & Security of transactions & Trust: follow-up & Business opportunity & Quality of life \\
\hline
\end{tabular}

Table 3: The benefits of e-government.

\section{The winners}

- E-government is a not a zero-sum game, but it is an all players winning game. The winners are:

- The e-government services provider that is the government of the country concerned.

- The e-government services individual receivers or customers that are the citizens of the country concerned.

- The businesses associated with different sectors using the egovernment services.

- The society as a whole, or the nation, where the e-government services are delivered.

Each e-government service can provide benefits to all three players. These benefits would be related to the eight main types of Table 3; and may also be of interdependent nature. Figure 2 views the winners and illustrates the interdependence of the benefits gained by them. 


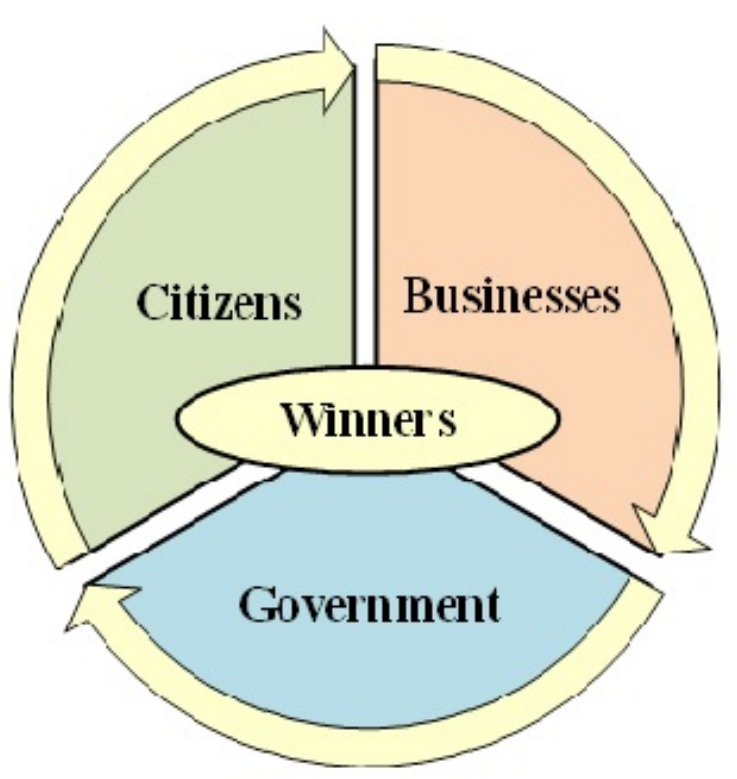

Figure 2: Winners of the benefits of e-government services.

\section{Approach Implementation}

This section is concerned with the question of how to implement the principles introduced above. For this purpose, a number of "steps" are derived; and these steps combine the "structured" view of the principles on the one hand, with the "top-down" gradual analysis on the other. The scope of the approach implementation is illustrated in Figure 3, and its resulting steps are described in the following.

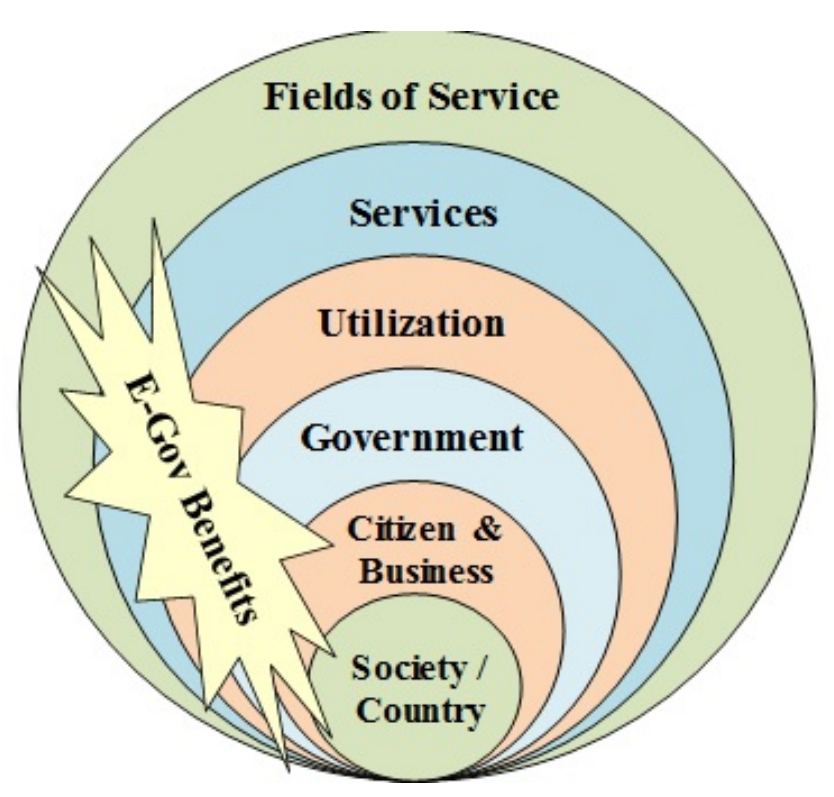

Figure 3: The scope of the approach implementation steps.

\section{Step 1: Field of service}

The first step is concerned with identifying the fields where egovernment services are provided. The UNDESA assessment method, given in Table 1, shows the basic fields of e-government services. Other fields may also be available. In addition, each field may be divided into subfields depending of the availability of service in these subfields.

\section{Step 2: Delivered services}

In this step, e-government services provided by each field and subfield should be identified. In this way, the services would be classified by fields and subfields. They can also be specified further according to the development stages of the "online services index" of UNDESA assessment method, which include: emerging, enhanced, transactional and connected services, as given in Table 1.

\section{Step 3: Utilization of services}

The benefits of the delivered services depend on their actual utilization; and this step is concerned with analyzing this utilization for each delivered service. This analysis would be based on the factors given in Table 2. The analysis would reveal how much each service is used relative to its potential level of use. This would help not only in assessing the state of utilization, but also in planning the future development of this utilization, and consequently in promoting the benefits of e-government.

\section{Step 4: Government benefits}

The assessment of government management benefits is the concern of this step. It considers the assessment of these benefits in three phases: for each service individually, followed by the level of the field of service, and then up to reaching the total level. The target outcome of this assessment would be guided by the eight types of benefits given in Table 3. In addition, it should be noted that the government benefits are related to the utilization of the services (Step 3), and not only to the existence of these services.

\section{Step 5: Citizens and businesses benefits}

This step is concerned with the assessment of the benefits gained by those who use the services, namely: the citizens and the business companies. Like the case of the assessment of government benefits, the eight types of benefits given in Table 3 should be taken into account, with regards to both: the citizens and the business. In addition, the benefits should be accumulated from the service level to the field level and up to the total level. Measuring using averages may also be needed in a similar way to the indicators taken per 100 population considered by the UNESA method of Table 1 .

\section{Step 6: Overall benefits}

At this final step, the need arises not only for the accumulation the results of all the above steps in an organized manner, but also for assessing the benefits of e-government to whole society. All benefits should now be: well-thought; well-structured and distributed; wellaccumulated and summed; and well-averaged, wherever needed.

It should be noted that the steps above are not necessarily sequential in all of their tasks, as some tasks of different steps can be performed simultaneously. 
Citation: Bakry SH, Bakry ZH, Muhaya FB (2016) An Approach for the Assessment of E-Government Benefits to Governments, citizens and Businesses. J Socialomics 5: 155. doi:10.41 72/2167-0358.1000155

Page 5 of 5

\section{Conclusions and Future Work}

The four basic principles presented here for the assessment of egovernment, and the six main steps concerned with the implementation of these principles, provide guidelines for the needed future practical assessment of e-government benefits to the various winners: the government, the citizens, and the businesses associated with different sectors. The authors are planning to move forward with the work toward translating the given principles and implementation steps into practical work. It is hoped that in the future, the assessment of e-government benefits would become a part of the international assessment and ranking of e-government.

\section{References}

1. Al-Osaimi K, Alheraish A, Bakry SH (2008) A STOP E-based approach for e-readiness assessment case studies. International Journal of Network Management (Wiley Inter-science) 18:65-75.
2. Esteve J, Joseph RC (2008) A comprehensive framework for the assessment of e-Government projects, Government Information Quarterly (Elsevier) 25:118-132.

3. UNDESA (2015) United Nations (UN) Department of Economic and Social Affairs (DESA), UN E-Government Survey.

4. Al-Almaee SM, Khayyat WR (2010) Strategic planning and supporting initiatives department: Saudi e-government program, 10th European Conference on e-Government, National Centre for Taxation Studies, University of Limerick, Ireland.

5. Jamal-Aldeen R, Bakry SH, Nouh A (2000) Performance-based evaluations of the tangible benefits of information networks with applications. International Journal of Network Management (Wiley Interscience) 10:2:91-101.

6. Bakry SH (2010) The intelligent e-government (in Arabic), A Seminar at Naif University, (Arab League), Riyadh, Saudi Arabia. 